\title{
The Use Of Indigenous Institutions In Developing Potential Equity Of Coastal Community (Desa Lampanairi Kecamatan Batauga Kabupaten Buton Selatan) Wa Ode Arsyiah ${ }^{1}$, Kuflia Muak Hara ${ }^{2}$
}

\author{
${ }^{1}$ State Administration Study Program, ${ }^{2}$ Sociology Study Programs, \\ Faculty of Social and Political Sciences, Dayanu University Ikhsanuddin \\ E-mail: waodearsyiah@unidayan.ac.id
}

\begin{abstract}
Abstrack
Abundant ecotourism potential can be developed through customary institutions capable of empowering the community and as government partners in developing ecotourism potential in the village of Lampuoranri, Bautauga District, South Buton Regency.

This study aims to describe indigenous institutions in developing the ecotourism potential of the coastal community of Lampanairi village and obtain information about the factors that influence ecotourism potential in the community in Lamporanri village, Batauga sub-district, South Buton district, such as Pilumuno We'e (Mountain Water Festival), Beach tourism, mountain tourism and many more will be explored for potential tourism objects.

This study uses qualitative descriptive analysis, the first stage is based on the mechanism in connecting the facts, data, and information that is available, in the form of words or verbal, from people and behaviors that are meant by the researcher. The second stage detects according to the object under study. The third stage interprets data generated through interviews, records, reports, documentation, etc. to be used for validity of research data.

The results showed that utilization of customary institutions in developing ecotourism potential in the coastal communities of Lampanairi village Batauga subdistrict of South Buton district has been done with the maximum although the customary institution in this village has not existed since the bloom from the village of Bola. But the villagers still uphold the local wisdom values that exist in the village, especially concerning the customary rituals of mountain water festivities at Wandoke Springs (Pilumuno We'e). The ritual of Pilumuno We'e is still done until now but unfortunately there has been no government involvement in supporting the ritual activity because the government has not yet known about this ritual and the village and society have not considered that this ritual can be made one of the interesting attractions in the village Lampanairi. It requires openness between the government and the village community so that local wisdom is maintained and become one of the tourism destinations that attract and can bring in foreign exchange if the management is done well. Awareness of Lampanairi villagers to the importance of preserving the forests by running the Pilumuno We'e cultural ritual followed by eating together, it shows that the community, village apparatus, traditional leaders, religious figures, community leaders still maintain the existing cultural values with support each other in organizing this ritual and serve as a gathering place for villagers.
\end{abstract}

Key Word: Customary Institutions, Coastal Communities and Ecotourism Potentials.

\section{Introduction}

\subsection{Background}

According to Law Number 10 of 2009 concerning Tourism, that is, tourism is organized based on the principle of benefit, family is fair and equitable, balance, independence, sustainability, participatory, sustainable, democratic, equality and unity. Tourism serves to fulfill the physical, spiritual and intellectual needs of every tourist with recreation and travel and increases state revenue to realize people's welfare. 
South Buton Regency is a new autonomous region that is rich in natural resources and has a variety of ethnic, racial, cultural and regional languages. Where each tribe has different customs in social life and has been institutionalized from generation to generation. Sujatmiko (2014: 169) states that "customary institutions are institutions that contain values, views of life, ideals, knowledge, beliefs and norms that are interrelated with each other".

Customary institutions have become a special force for the government of South Buton Regency as a community that has strength in terms of community empowerment. Adimihardja in Bambang Sunaryo (2013: 215) states that "empowerment is improving dignity, self-confidence and self-esteem maintained through the order of local cultural values". Customary institutions can be encouraged to develop existing ecotourism potential in Lampanairi Village, Batauga District, South Buton Regency. The Wold Conservation Union (WCU) in Iwan Nugroho (2011: 15) defines ecotourism is travel to areas that are still pristine natural environment, by respecting their cultural and natural heritage, supporting conservation efforts, not producing negative impacts, and socio-economic benefits and respecting local participation".

The area of South Buton Regency is very strategic supported by adequate facilities and infrastructure, both transportation, road infrastructure and other facilities are considered sufficient. Its ecotourism potential is also not attractive with regions outside South Buton, it's just that the weaknesses have not been fully touched by the government to be used as tourist attractions which later will be commercially valuable for the benefit of many people, traditional institutions also need to be managed with a better system, given guidance and assistance so that the sense of self-esteem arises in terms of managing the ecotourism potential in the area.

Based on the initial observations of researchers, traditional leaders in Lampanairi village have 4 (four) people who have functions: 1). As a customary leader to build a house, 2). As a customary leader to open a garden (mountain parika). 3). As customary leader for water cleaning (Pande Pidawu). 4). As customary leader for marine products (Parika Laut). The traditional party that will be held in the near future is Pilumono We'e or Water Mountain Party which is held 2 (two) times a year at the beginning of the planting season which is every June and December precisely on the mountain in the village of Lampanairi.

The development of tourism areas in South Buton regency in cultural and tourism development through tourism area development strategies is carried out by looking at the proximity of tourism objects, as well as optimizing resources and funds for developing tourism service facilities. In the development of culture and tourism strategic issues are needed in the development of culture and tourism, namely: a). Not optimal efforts to preserve regional culture. b). The competitiveness of tourism destinations is not yet optimal. c). The lack of optimal competence and capability of tourism human resources. d). Synergy and partnership is not optimal yet. e). not yet optimal utilization of data and information.

Based on the phenomenon that is needed awareness and good cooperation by all parties how the traditional institutions in Lampanairi village are used to multiply the potential of ecotourism to be developed later.

To be able to provide a clear picture of tourism potential and development, in this study researchers are interested in taking the title The Use Of Indigenous Institutions In Developing Potential Equity Of Coastal Community (Desa Lampanairi Kecamatan Batauga Kabupaten Buton Selatan)

\subsection{Problem Formulation}

Based on the identification of the problem above, the formulation of the problem is:

1. What is the use of traditional institutions in developing ecotourism potential in coastal communities in Lampanairi Village, Batauga District, South Buton Regency?

2. What factors influence the increase of ecotourism potential in coastal communities in Lampanairi Village, Batauga District, South Buton Regency? 


\subsection{Research Purposes}

The purpose of this study is:

1. To describe the use of adat institutions in developing ecotourism potential in coastal communities in Lampanairi village, Batauga sub-district, South Buton regency.

2. To describe the factors that influence the increase of ecotourism potential in coastal communities of Lampanairi Village, Batauga District, South Buton Regency.

\subsection{Benefits of research}

\subsubsection{Theoretical Benefits}

The theoretical benefits in this study are as follows:

1. This research is expected to be useful for the development of science in general and in particular with regard to the use of customary institutions in developing ecotourism potential in coastal communities in Lampanairi village, Batauga Subdistrict, South Buton Regency.

2. As reference material for anyone who wants to know the development of the tourism sector through the use of customary institutions in developing ecotourism potential in coastal communities in Lampanairi village, Batauga District, South Buton Regency.

3. As a comparison material for further researchers who want to explore the use of traditional institutions in developing ecotourism potential in coastal communities in Lampanairi village, Batauga subdistrict, South Buton district.

\subsubsection{Practical Benefits}

1. For the Department of Culture and Tourism of South Buton Regency

The results of this study can be used as input for the Culture and Tourism Office to better organize the development of coastal community ecotourism potential in Lampanairi village, Batauga Subdistrict, South Buton District.

2. For the Government of South Buton Regency

The results of this study can be used as material for South Buton District government policy in improving the quality of service at the Department of Culture and Tourism of South Buton Regency.

3. This research can be a reference in every subsequent policy formulation

\section{Research Methods}

\subsection{Research sites}

The location of this study was carried out in Lampanairi Village, Batauga District, South Buton Regency with ecotourism potential that could be developed through the use of traditional institutions.

\subsection{Research design}

The research design used in this study is descriptive qualitative, which is to explain the facts and social phenomena that occur objectively. The aim is to explain the phenomenon of the use of adat institutions in developing ecotourism potential of coastal communities in Lampanairi village, Batauga sub-district, South Buton district.

\subsection{Data Types and Sources}

The type of data in this study is the data obtained are classified into primary data and secondary data. Primary data is data collected by observation and direct interviews from the main sources conducted based on guidelines that have been made and direct observation of respondents in the field.

While secondary data is data obtained through literature studies conducted by looking at and studying various materials such as books, papers, scientific papers, journals, including various regulations relating to the object of research. 


\subsection{Data collection technique}

Data collection used in this study are:

1. Interview guide is a technique used by researchers in collecting data by conducting direct question and answer with the informant until accurate data is obtained.

2. Observation, namely data collection techniques by conducting direct observations at the research location.

3. Documentation is the technique of collecting data by tracing documents related to research on the use of adat institutions in developing ecotourism potential of coastal communities in Lampanairi village, Batauga sub-district, South Buton district, as well as other relevant documents.

\subsection{Data analysis technique}

Data analysis techniques are the process of arranging data sequences, organizing them into a basic pattern, category and unit description. Data analysis techniques used in this study both primary data and secondary data will be processed or analyzed qualitatively qualitative, carried out based on the reasoning ability of researchers in connecting the facts, data, and information available, in the form of written or oral words, from people and behavior observed by researchers. Then analyze according to the object under study and interpret the data obtained through interviews, notes, reports, documentation, and others to obtain the validity of the research data.

\section{Results and discussion}

\subsection{The Role of Government, Community and Customary Leaders in Developing Coastal Ecotourism Potential.}

MK Informant. As a government party (Tourism and Creative Economy service in South Buton district) 50 years old said that the government has not been involved in Pilumuno activities We'e not even aware of the ritual. He hoped that the village or the Lampanairi village community would be open to the government on this matter, so that the government could socialize it both through print and online media in this case social media so that it could become one of the cultural and natural tourism objects that would bring in foreign exchange for the local area. In addition, government involvement is very important because it can help facilitate the infrastructure to the Wandoke spring rituals where the government really hopes for information from the village regarding Pilumuno We'e ritual activities that can be used as one of the local community attractions (interview, 16 May 2018)

LS informant, aged 55 years a religious figure (Moji) said that the role of the government in developing the ecotourism potential of the coastal community in Lampanairi village had not been done optimally. The tradition of mountain water cleansing (Pilumuno We'e) has not involved the local government, this tradition is carried out, village officials, traditional leaders, religious leaders and almost all village communities. (Interview on May 16, 2018) The cleansing ritual begins with the traditional leader (Pande Pidawu) who opens the flow of water then the community, especially men, work together to clean up the flow of water in the Wandoke spring which consists of 3 springs simultaneously afterwards. all finished, the mothers prepare food that has been prepared from their homes and then serve the food and eat together. This joint eating ritual is preceded by men then the women and after finishing it, they take a bath in the river. The Pilumuno We'e tradition is an important tradition to do because maintaining this tradition means safeguarding the forest from illegal logging and of course the discharge and quality of water that is a source of clean water for coastal communities will be maintained.

Likewise, the LD informant of a 44-year-old male Head of the Lampanairi Village said that the government's role in increasing the potential of ecotourism in my village has not been touched by the government. All activities concerning Pilumuno We'e only involve village officials, traditional leaders, community leaders and village residents because they have not thought about involving the government. 
I consider the ritual that is carried out in the Wandoke spring is just an ordinary annual activity. And have not seen the opportunity to bring tourists, especially cultural tourism and natural tourism. Admittedly, the people in my village are people who live on the coast but are very dependent on the Wandoke spring because all the water needs of the people from the village come from that place. (Interview on May 15, 2018) By performing Pilumuno We'e rituals, the community indirectly keeps springs from dirt that can clog running water and at the same time safeguards the forest from illegal logging. If the forest is maintained, the springs will remain and the community will meet their water needs. But what has not been done is to socialize this ritual activity so that it can become one of the local wisdoms that can bring people outside the village to come to visit and be directly involved in the traditional ritual.

LK, a 53-year-old man who works as a device in Lampanairi village said that the government's role in developing the ecotourism potential of coastal communities has not been done maximally, this is because the government does not know about the Pilumuno We'e ritual activities. We have not thought so far, we consider this ritual only as an ordinary annual ritual carried out by local villagers. Although there is no traditional institution in this village yet, the village community really appreciates the decisions that have been taken by traditional leaders, especially regarding traditional activities, especially in terms of Pilumuno We'e and Pindoaka rituals. Both rituals are carried out 2 times a year and for cleaning Wandoke springs (Pilumuno We'e) carried out in the middle of the year and for Pindoaka it is carried out every turn of the season both west to east and from east to west. The Pilumuno We'e ritual besides being a routine activity for the community to gather in the Wandoke spring can also be beneficial in forest conservation. (Interview, May 15, 2018). Forests that are maintained automatically will have abundant water discharge and coastal communities will not lack water. Unfortunately the Wandoke spring cleaning ritual was used as one of the cultural tourism activities and only became the consumption of the villagers. Therefore, it is highly expected that the government will participate in promoting cultural tourism so that with good promotion the Pilumuno We'e ritual will be known outside the village and even abroad. Therefore, government involvement is needed to build supporting infrastructure, promote and collaborate with rural communities to bring in both local and international tourists, although this is not easy but if planned carefully by involving the government, community and stakeholders/private parties Pilumuno we'e ritual This will be one of the most interesting cultural attractions.

LZ informants, aged 77 years as traditional leaders in Lampanairi village said that there was no government involvement in the Pilumuno We'e ritual because we thought that this ritual was only a ritual that was our duty to the villagers and had not thought to promote it outside the village. This ritual procedure is carried out by deliberation between traditional leaders, religious leaders, community leaders and village heads to determine the exact time when the ritual will be held. After the time has been determined, the socialization to carry out this ritual is done through word of mouth information. The customary leader seeks the best time to conduct the ritual by discussing with the village parents. Decisions regarding the timing of ritual implementation are determined by the customary leader and obeyed by all village communities. Wandoke spring cleaning rituals held on July 5, 2018 have not involved the local government and only done by villagers. This Wandoke spring cleaning ritual is done starting at 6:30 a.m. which starts with Kabelai (opening first) by taking a little water that comes out of the spring and then storing it and after cleaning, the water will be returned to the spring with the intention that the eyes Wandoke water will continue to exist and not dry. (Interview on May 15, 2018) after being completed in Belai, after the men collaborated, they carried out a simultaneous cleaning in 3 (three) points of the spring. After cleaning the dirt that clogs the springs, the ritual of eating together is held. The food is voluntarily made by women and village women and all food is collected at one and the men who first take food and then continue with the women. the place. This activity can also be a friendship activity between the local community members because with this ritual almost all the residents of the pesisi village gather in the Wandoke spring. After they finish eating continue with bathing and all those present are obliged to take a bath. A few years ago usually after the completion of ritual activities in the 
spring, the evening continued with a joget brsama event but it was no longer done for the safety of the village. The coastal residents of Lampanairi village really appreciate the Pilumuno We'e ritual because the Wandoke water source is the only source of clean water in the village. Only pay Rp. 2500, - per month the water flows to the homes of coastal people very smoothly. Public awareness of the importance of preserving forests and Pilumuno We'e traditions is still being preserved.

\subsection{Factors That Influence The Increase Of Ecotourism Potential}

\subsubsection{Traveler}

TD informant, a 66-year-old man as a community leader said that Pilumuno We'e rituals were not known by residents outside the village so the villagers had not determined the characteristics of tourists who were expected by the local community, but the tourists expected by the people who are willing to participate in preserving the environment and safeguarding the area of tourism so that the forest remains sustainable springs are maintained, ritual culture is preserved and people living in coastal areas have no difficulty in clean water because the spring is maintained. (Interview on 12 May 2018). Through the Pilumuno We'e ritual, it is expected to bring tourists to become one of the interesting cultural and natural tourism attractions.

\subsubsection{Transportation}

LN informants, a 49-year-old man as the head of the Kakinauwe III hamlet said that to come to the village we could use transportation for private vehicles, both motorbikes and cars, and there were also public transportation from Baubau to Lampanairi village, South Buton district. Similarly, what was said by LB informants, a 41-year-old man as the head of Langkarusa hamlet said the same thing regarding transportation to Lampanairi village, there were no public transportation problems that were easy and very smooth. With the adequate transportation of tourists who want to follow the rituals of Pilumuno culture, we can easily come to the Wandoke spring.

\subsubsection{Service facilities}

LK, a 53-year-old man who works as a device in the Lampanairi village said that the facilities available in Lampanairi village already existed but were not adequate. For example there are no adequate hotels / inns, there are no restaurants, banks, post offices and hospitals as well as sampat dumps. Existing facilities are still just a small shop and Pustu, and supporting structures such as clean water, electricity and telecommunications are available.

\subsubsection{Local community}

Readiness and support of local communities in receiving tourists in Lampanairi village plays an important role in planning tourism development in the future. Tourism is one of the fields that contribute a lot to the country's foreign exchange aside from the petroleum and gas sector, plays a role in expanding employment, encouraging and equating regional development, improving the welfare and prosperity of the community. Therefore, tourism development needs to get priority in its national development, it needs support from the community and the local government, in planning the development of Pilumuno We'e cultural ritual attractions, which are the rituals of coastal village communities that continue to be carried out. This local wisdom is actually maintained and even socialized to tourists so that this culture remains and is not extinct because the community is the host of a destination. This ritual if it continues to exist, the source of the water will still be there because the forest in the Wandoke spring area will be maintained and the coastal community will continue to meet their water needs. LD, a 44-year-old man, head of the Lampanairi village, said that the local community's acceptance of the existing ecotourism potential was also not interesting with the areas outside our village, only the weaknesses had not been 
fully touched by the government to be used as places tours that will be commercially valuable for the benefit of many people, (Interview on 15 May 2018)

\subsubsection{Information}

Information provided by the government and the local community regarding tourist destinations that will be visited so that tourists can make decisions to come visit should be available. In the Wandoke spring ritual tourism activity, information is not available, either in the form of pamphlets, brochures, or online media which can be used as guidance for tourists to come to see the Pilumuno We'e ritual. The local community has not thought to make this ritual a cultural tourism object, therefore it requires collaboration between the local government and local communities to make this ritual interesting and worth visiting.

\section{Closing}

\subsection{Conclusion}

1. Utilization of customary institutions in developing ecotourism potential in coastal communities in Lampanairi village, Batauga sub-district, South Buton regency, has been carried out optimally, even though the traditional institutions in this village have ceased to exist since they were released from the village of Bola. However, the village community still upholds the values of local wisdom in the village, especially regarding the traditional ritual of mountain water parties in the Wandoke spring (Pilumuno We'e). Pilumuno We'e rituals are still being carried out to date but unfortunately there is no government involvement in supporting the ritual activities because the government does not yet know about this ritual and the village and the community do not consider that this ritual can be used as one of the interesting attractions in the village Lampanairi. Therefore, it requires openness between the government and rural communities so that local wisdom is maintained and becomes one of the attractive tourism destinations and can bring in foreign exchange if the management is carried out properly.

2. Lampanairi village community awareness of the importance of preserving the forest by carrying out the rituals of Pilumuno We'e culture followed by eating together, this shows that the community, village officials, traditional leaders, religious leaders, community leaders still maintain cultural values that there is mutual support in the implementation of this ritual and is used as a gathering place for villagers.

\subsection{Suggestion}

1. The government should have data on traditions, rituals, natural attractions, cultural tourism, artificial tourism in the village so that the potential is easier to promote. There needs to be a touch from the government and stakeholders to make tourism places that are commercially valuable for the benefit of many people.

2. There needs to be coordination between the government, the local community and guidance and assistance in managing ecotourism potential in the area to increase tourist visits both locally and foreign tourists.

\section{Bibliography}

\section{A. Books}

Ansohori. Yusak. 2010. Tourism Board (Strategi Promosi pariwisata Daerah). Surabaya: Putra Media Nusantara.

Damanik, Phil Janianton. 2013. Pariwisata Indonesia (Antara Peluang dan Tantangan). Yogyakarta: Pustaka Pelajar. 
Damanik dan Weber. 2006. Perencanaan Ekowisata; Dari Teori ke Aplikasi. Yogyakarta: Penerbit ANDI.

Hadiwijoyo, Sakti Suryo. 2012. Perencanaan Pariwisata Perdesaan Berbasis Masyarakat (sebuah pendekatan konsep). Yogyakarta: Graha Ilmu.

Nugroho, Iwan. 2011. Ekowisata dan Pembangunan Berkelanjutan. Yogyakarta: Pustaka Belajar.

Nurdiyansah. 2014. Peluang dan Tantangan Pariwisata Indonesia. Bandung: Alfabeta.

Ridwan, Mohammad. 2012. Perencanaan dan Pengembangan Pariwisata. Jakarta: P.T. SOFMEDIA.

Sugiono. 2014. Metode Penelitian Kuantitaf, Kualitatif dan R\&D. Bandung: Alfabeta.

Sunaryo, Bambang. 2013. Kebijakan Pembangunan Destinasi Pariwisata (konsep dan aplikasinya di Indonesia). Yogyakarta: Gava Media.

Sujatmiko, Eko. 2014. Kamus Ilmu Pengetahuan Sosial. Cetakan 1. Surakarta: Penerbit Aksara Sinergi Media.

Zaenuri, Muchamad. 2012. Perencanaan Strategis Kepariwisataan Daerah (Konsep dan Aplikasi). Yogyakarta: E-Gov Publishing.

\section{B. Legislation}

Peraturan Lembaga Adat Besar Republik Indonesia Nomor : 1 Tahun 2009 tentang Pemberdayaan, Pelestarian, Perlindungan Dan Pengembangan Adat Istiadat Dan Lembaga Adat Dalam Wilayah Negara Republik Indonesia.

Permendagri No.5 Tahun 2007 Tentang Pedoman Penataan Lembaga Kemasyarakatan. 